\title{
PENGETAHUAN MASYARAKAT TENTANG JENIS TUMBUHAN OBAT DI KAWASAN TAMAN WISATA ALAM MADAPANGGA SUMBAWA
}

\author{
COMMUNITY KNOWLEDGE OF THE MEDICINAL PLANT TYPES IN NATURAL TOURISM AREA OF \\ MADAPANGGA SUMBAWA.
}

\author{
Novi Ani*, Immy Suci Rohyani, Maulana Ustadz
}

Program Studi Biologi, Fakultas Matematika dan Ilmu Pengetahuan Alam, Universitas Mataram. Jalan Majapahit No. 62, 83125, Indonesia

*Email: novianipribadi2@gmail.com

Diterima: 20 Juli 2018. Disetujui: 9 September 20 18. Dipublikasikan: 29 September 2018

\begin{abstract}
Abstrak. Pemanfaatan tumbuhan lokal sebagai sumber obat-obatan merupakan alternatif yang dapat dikembangkan, tumbuhan obat dapat menjadi alternatif pilihan untuk mengobati berbagai jenis penyakit. Hal ini dikarenakan efek yang ditimbulkan dari penggunaan obat tradisional (jamu atau herbal), lebih kecil dibandingkan penggunaan obat kimia buatan (modern). Pengetahuan tradisional ini merupakan unsur budaya yang muncul dari pengalaman individu yang disebabkan adanya interaksi dengan lingkungannya dan diwariskan secara turun temurun. Penelitian ini bertujuan mengetahui seberapa besar pengetahuan masyarakat tentang jenis tumbuhan obat di Kawasan TWA Madapangga, Sumbawa. Penelitian ini bersifat deskriptif ekploratif, yang dilaksanakan pada bulan Juli-Agustus 2017. Lokasi penelitian yaitu di Desa Ndano dan TWA Madapangga. Teknik pengumpulan data dengan metode Purposive Sampling dan Snowball Sampling. Penelitian ini menggunakan penyajian data dengan diagram batang dan teks yang bersifat naratif. Diperoleh sebanyak 10 responden yang memiliki tingkat pengetahuan lebih dari 90\%, 14 responden yang memiliki tingkat pengetahuan antara $70 \%-90 \%$, serta 4 responden yang memiliki tingkat pengetahuan kurang dari $70 \%$. Hasil wawancara dan identifikasi tumbuhan, terdapat 45 spesies tumbuhan dari 27 Famili yang digunakan masyarakat di Sekitar TWA Madapangga untuk bahan pengobatan berbagai penyakit.
\end{abstract}

Kata Kunci : Tumbuhan obat, pengetahuan masyarakat, TWA Madapangga, Sumbawa

\begin{abstract}
Utilization of local plants as a source of drugs is an alternative that can be developed, medicinal plants can be an alternative option to treat various types of diseases. This is because the effects arising from the use of traditional medicine (herbal medicine or herbal), smaller than the use of artificial chemicals (modern). This traditional knowledge is a cultural element that emerges from the individual experience caused by the interaction with the environment and passed down from generation to generation. This study aims to find out how much community knowledge about the types of medicinal plants in TWA Madapangga Area, Sumbawa. This research is descriptive explorative, conducted in July-August 2017. The research location is in Ndano Village and TWA Madapangga. Technique of collecting data by Purposive Sampling and Snowball Sampling method. This research uses data presentation with narrative bar and text diagrams. 10 respondents have knowledge level of more than 90\%, 14 respondents have knowledge level between $70 \%-90 \%$, and 4 respondents who have knowledge level less than 70\%. Results of interviews and plant identification, there are 45 plant species from 27 families used by the community around TWA Madapangga for the treatment of various diseases.
\end{abstract}

Keywords: Medicinal plants, community knowledge, TWA Madapangga, Sumbawa

\section{PENDAHULUAN}

Tumbuhan obat merupakan tumbuhan berkhasiat obat yang dapat menghilangkan rasa sakit, meningkatkan daya tahan tubuh, membunuh bibit penyakit dan memperbaiki organ yang rusak. Tumbuhan obat juga dapat menghambat pertumbuhan sel-sel yang tidak normal seperti tumor, kanker. Hal-hal penting inilah yang memicu masyarakat untuk tetap mempertahankan pemanfaatan tanaman obat sebagai alternatif pengobatan secara tradisional [1-5].

Pemanfaatan tumbuhan lokal sebagai sumber obat-obatan merupakan alternatif yang dapat dikembangkan, tumbuhan obat dapat menjadi alternatif pilihan untuk mengobati berbagai jenis penyakit. Hal ini dikarenakan efek yang ditimbulkan dari penggunaan obat tradisional (jamu atau herbal), lebih kecil dibandingkan penggunaan obat kimia buatan (modern) [6-10].

Setiap etnis/suku memiliki pengetahuan tradisional untuk memanfaatkan tumbuhan sebagai obat. Pengetahuan tradisional ini merupakan unsur budaya yang muncul dari pengalaman individu yang disebabkan adanya interaksi dengan lingkungannya dan diwariskan secara turun temurun yang bertujuan untuk mempertahankan hidup, karena baik disadari 
maupun tidak dalam mempertahankan kelangsungan hidupnya, manusia akan selalu bergantung pada lingkungannya [11].

Ilmu pengobatan terakumulasi pada masing-masing kelompok masyarakat. Azas penyembuhan dalam semua sistem kesehatan selalu didasarkan pada kepercayaan tentang sebab terjadinya penyakit yang disebut etiologi penyakit. Etiologi penyakit dapat dibedakan dalam dua macam, etiologipersonalistik dan etiologi naturalistik. Dalam etiologi personalistik, keadaan sakit dipandang sebagai sebab adanya campur tangan agen atau perantara seperti orang halus, jin, setan, hantu atau roh tertentu. Seorang jatuh sakit karena sebab-sebab tersebut $[12,13]$.

Taman Wisata Alam Madapangga telah ditunjuk berdasarkan Tata Guna Hutan Kesepakatan dan telah ditata batas (Berita Acara Tata Batas Fungsi, tanggal 12 Januari 1995) serta diperkuat dengan Surat Keputusan Menteri Kehutanan dan Perkebunan No. 418/Kpts-II/1999 tanggal 15 Juni 1999. Taman Wisata Alam Madapangga termasuk dalam kelompok hutan Toffo Rompu RTK 65 seluas $232 \mathrm{Ha}$ dengan panjang batas fungsi 2,7 Km. Secara geografis Taman Wisata Alam Madapangga terletak pada $8^{\circ} 15^{\prime}-8^{\circ} 45^{\prime} \mathrm{LS}$ dan $118^{\circ} 30^{\prime}-118^{\circ} 45^{\prime} \mathrm{BT}$, sedangkan secara administratif pemerintahan terletak di Desa Ndano Kecamatan Madapangga Kabupaten Bima. Taman Wisata Alam Madapangga memiliki potensi tumbuhan yang dapat dimanfaatkan sebagai obat. sebagai contoh, pada bagian utara Taman Wisata Alam Madapangga, terdapat banyak jenis pohon endemik yaitu Kayu Songga (Strychnos ligustrina), yang memiliki khasiat sebagai obat malaria. Selain jenis Kayu Songga terdapat jenis lain yang dapat digunakan sebagai obat yaitu Pulai (Alstonia scholaris), Bebatu/Tula (Alstonia spectabilis), Bidara (Zyzypus swagery) jenis Golkar, Sringgi, Taride dan Tapak Kuda.

Penelitian tentang tumbuhan obat ol _masyarakat di sekitar Kawasan Taman Wisata Alam Madapangga belum pernah dilakukan, walaupun upaya kesehatan melalui pemanfaatan obat tradisional dari tumbuh-tumbuhan ini telah dikenal masyarakat dari dulu hingga saat ini. Oleh karena itu, peneliti melakukan penelitian yang berkaitan dengan "Pengetahuan Masyarakat Di Kawasan Taman Wisata Alam Madapangga Tentang Jenis Tumbuhan Obat". Adapun rumusan masalah dalam penelitian ini adalah seberapa besar pengetahuan masyarakat tentang jenis tumbuhan obat di Kawasan TWA Madapangga. Tujuan dalam penelitian ini adalah mengetahui seberapa besar pengetahuan masyarakat tentang jenis tumbuhan obat di Kawasan TWA Madapangga.

\section{METODE PENELITIAN}

Penelitian ini bersifat deskriptif eksploratif, yaitu penelitian yang menggambarkan fakta, keadaan, dan fenomena yang terjadi saat penelitian berlangsung dan menyajikan data apa adanya sesuai dengan objek yang diteliti. Penelitian ini dilakukan pada bulan Juli-Agustus 2017. Lokasi pengambilan sampel yaitu di dalam Kawasan TWA Madapangga dan sekitar Kawasan TWA Madapangga Kabupaten Bima, Nusa Tenggara Barat.

Alat yang digunakan dalam penelitian ini antara lain: Perlengkapan wawancara: pulpen, buku, kamera untuk pendokumentasian, dokumen atau pustaka yang terkait dengan penelitian. Teknik pengumpulan data dalam penelitian ini terdiri dari dokumentasi, wawancara dan angket.

Tabel 4.1Skala Likert

\begin{tabular}{llc}
\hline No. & \multicolumn{1}{c}{ Pilihan respons } & Skor \\
\hline 1. & Sangat tahu & 4 \\
2. & Tahu & 3 \\
3. & Kurang tahu & 2 \\
4. & Tidak tahu & 1 \\
\hline
\end{tabular}

Pengumpulan data dengan angket ini bertujuan untuk mengetahui tingkat pengetahuan masyarakat di Kawasan Taman Wisata Alam Madapangga tentang jenis dan pemanfaatan tumbuhan obat. Wawancara dengan penentuan daerah sampling dengan metode Purposive Sampling dan penentuan narasumber dengan Metode Snowball Sampling.

\section{Analisis Data}

Reduksi data dalam penelitian ini dilakukan dengan cara:

a) Data hasil wawancara digolongkan dengan mengelompokkan jawaban dari responden yang sama

b) Data yang diperoleh dari angket dianalisis secara kuantitatif dengan menggunakan rumus sebagai berikut:

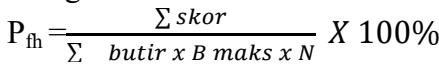

Keterangan:

$\mathrm{P}_{\mathrm{fh}}=$ Persentase Tingkat Pengetahuan Masyarakat

Sskor = Jumlah Butir Angket

B maks = Jumlah Bobot Maksimal Angket

$\mathrm{N} \quad=$ Jumlah Responden

Untuk mengkategorikan tingkat pengetahuan masyarakat mengenai jenis manfaat tanaman obat, maka digunakan criterian ideal theoretic berikut.

Tabel 4.2 Criterian ideal theoretic [12]

\begin{tabular}{cc}
\hline Persentase & Skor \\
\hline $81-100$ & Sangat baik \\
$61-80$ & Baik \\
$41-60$ & Cukup baik \\
$21-40$ & Buruk
\end{tabular}

Penelitian ini menggunakan penyajian data dengan diagram batang dan teks yang bersifat naratif. 


\section{HASIL DAN PEMBAHASAN \\ Karakteristik Responden}

Berdasarkan hasil wawancara yang diperoleh bahwa pendidikan masyarakat disekitar kawasan Taman Wisata Alam Madapangga cukup bervariasi. Namun ada sebagian masyarakat yang menjadi responden di Desa Ndano memiliki tingkat pendidikan formal yaitu Tidak sekolah sampai SD. Masyarakat yang menjadi responden bermata pencaharian sebagai petani dan buruh. Masyarakat bertani dilahan milk sendiri yang sudah turun temurun diwariskan. Umur responden bervariasi yaitu remaja dari umur 18-20 tahun, dewasa dari umur 21-59 tahun, dan lansia dari umur 60-72 tahun. Hal ini dapat dilihat bahwa umur produktif pada responden didominasi oleh kelas umur dewasa. Jumlah laki-laki lebih banyak yaitu sebanyak 18 orang dan wanita 12 orang, dari 30 responden yang diwawancarai.

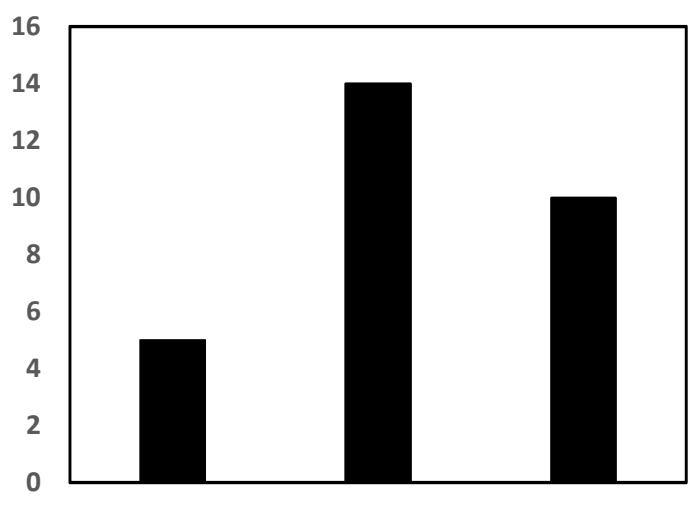

Kurang dari 70\% Antara 70\%-90\% Lebih dari 90\%

Gambar 1. Persentase Tingkat Pengetahuan Masyarakat tentang Tumbuhan Obat

Gambar 1 menunjukkan bahwa hasil analisis yang dilakukan terhadap 30 responden diperoleh sebanyak 10 responden yang memiliki tingkat pengetahuan lebih dari 90\%, 14 responden yang memiliki tingkat pengetahuan antara $70 \%$ $90 \%$, serta 4 responden yang memiliki tingkat pengetahuan kurang dari $70 \%$. Kondisi ini menunjukkan bahwa menunjukkan bahwa tingkat pengetahuan masyarakat tentang pengetahuan tumbuhan obat adalah sangat tinggi. Hasil wawancara yang di peroleh bahwa sebagian besar semua masyarakat di sekitar kawasan TWA Madapangga mengetahui jenis-jenis tumbuhan obat. Pengetahuan masyarakat ini merupakan warisan turun-termurun yang mereka dapat dari orang tua mereka pada zaman dulu. Pengetahuan ini memberikan informasi bahwa masyarakat memiliki potensi yang cukup tinggi untuk melakukan kegiatan membudidayakan tumbuhan obat di kebun atau pekarangan rumah masyarakat.

\section{Keanekaragaman Tumbuhan Obat di Madapangga Berdasarkan Pengetahuan Masyarakat}

Berdasarkan hasil wawancara dan identifikasi tumbuhan, terdapat 45 spesies tumbuhan dari 27 Famili yang digunakan masyarakat di Sekitar Taman Wisata Alam Madapangga sebagai bahan pengobatan berbagai penyakit. Terdapat beberapa tumbuhan obat yang tidak ditemukan karena keadaan sedang pada musim kemarau. Persentasi tingkat pengetahuan pada tumbuhan berikut merupakan tumbuhan yang didapatkan setelah wawancara sebanyak yaitu Lidah ular (Hedyotis corymbosa), Cincau rambat (Cyclea barbata), Sirih (Piper Betle L.), Sintrong (Crassocephalum crepidioides), Bandotan (Ageratum conyzoides), Kemiri (Aleurites moluccana), Jambu mede (Anacardiumoccidentale), Pare (Momordica charantia), Bidara (Ziziphus mauritiana), Cocor bebek (Kalanchoe pinnata), Bayam duri (Amaranthus spinosus), Kelor (Moringa oleifera), Jeruk kikit (Triphasia trifolia), Pegagan (Centella asiatica), dan Kemangi hutan (Ocimum sp.).

Jenis tumbuhan obat yang terdapat pada lokasi pengamatan dapat di lihat pada Tabel 1 . (lampiran). Tabel 1. dapat dilihat bahwa jenis tumbuhan dari Famili Euphorbiaceae, Fabaceaemerupakan bahan yang paling banyak digunakan sebagai bahan obat yaitu sebanyak 4 spesies. Famili Rutaceae, Asteraceae dan Annonaceae digunakan 3 spesies. Selanjutnya dari Famili Rubiaceae, Apocynaceae, Myrtaceae, Piperaceae, Menispermaceae dan Zingiberaceae masing-masing digunakan 2 spesies, sedangkan Famili lainnya masing-masing hanya 1 spesies.

Gambar 2 menunjukkan jumlah tumbuhan obat yang digunakan berdasarkan famili. Famili yang paling tinggi persentasenya yaitu Famili Euphorbiaceae dan Fabaceaemasing-masing sebanyak 4 spesies yaitu Famili Euphorbiaceae (Euphorbia thymifolia, Aleurites moluccana, Jatropha curcas, Anacardium occidentale), FamiliFabaceae (Tamarindus indica, Caesalpinia sappan, Cassia alata, Leucaena leucocephala).

Tumbuhan dari Familia Fabaceae merupakan famili tumbuhan yang besar, dengan 650 genus dan melebihi 18.000 species. Menurut ilmu kemotaksonomi, tumbuhan dalam suku yang sama mengandung senyawa dengan kerangka struktur kimia sama sehingga berpotensi memiliki aktivitas biologis yang sama. Sebagian besar tanaman fabaceae mengandung senyawa flavonoid yang telah dilaporkan efektif menghambat peroksidasi asam linoleat dan mencegah pembentukan anion superoksida antara lain quersetin, isorhamnetin dan rhamnazin. Senyawa ini potensial melawan peroksidasi mikrosomal lipid yang diinduksi oleh Fe(III)ADP/NADPH [12]. 
Tabel 1 Tabel Jenis Tumbuhan obat di Kawasan TWA Madapangga

\begin{tabular}{|c|c|c|c|c|c|}
\hline \multirow[b]{2}{*}{ No. } & \multirow[b]{2}{*}{ Family } & \multicolumn{3}{|c|}{ Nama Tumbuhan } & \multirow{2}{*}{$\begin{array}{l}\text { Persentasi } \\
\text { Tingkat } \\
\text { Pengetahuan }\end{array}$} \\
\hline & & Nama Spesies & Nama Indonesia & Nama Lokal & \\
\hline 1 & Meliaceae & Swietenia mahagoni & Mahoni & Mahoni & $84 \%$ \\
\hline \multirow{2}{*}{2} & \multirow{2}{*}{ Apocynaceae } & Alstonia scholaris & Pulai & Tula & $84 \%$ \\
\hline & & Alstonia spectabilis & Pulai & Rida & $85 \%$ \\
\hline 3 & Loganiaceace & Strychnos lucida & $\begin{array}{l}\text { Bidara Laut, Kayu } \\
\text { Ular }\end{array}$ & Songga & $91 \%$ \\
\hline \multirow{4}{*}{4} & \multirow{4}{*}{ Fabaceae } & Tamarindus indica & Asam & Mangge & $91 \%$ \\
\hline & & Caesalpinia sappan & Secang & Supa & $65 \%$ \\
\hline & & Cassia alata & Ketapeng Cina & Kakapi Na'e & $83 \%$ \\
\hline & & Leucaena leucocephala & Lamtoro & Pate & $87 \%$ \\
\hline \multirow[b]{2}{*}{5} & \multirow[b]{2}{*}{ Rubiaceae } & Morinda citrifolia & Mengkudu & Nonu & $75 \%$ \\
\hline & & Hedyotis corymbosa & Lidah ular & Rera sawa doro & - \\
\hline \multirow{2}{*}{6} & \multirow{3}{*}{ Rutaceae } & Citrus hystrix & Jeruk Purut & Dungga Mbudi & $84 \%$ \\
\hline & & Citrus aurantifolia & Jeruk Nipis & Dungga Ncia & $88 \%$ \\
\hline 7 & & Triphasia trifolia & Jeruk Kikit & - & - \\
\hline \multirow[b]{2}{*}{8} & \multirow[b]{2}{*}{ Myrtaceae } & Eugenia cumini & Duwet/Jamblang & Duwe & $87 \%$ \\
\hline & & Psidium guajava & Jambu Batu & Jambu Doro & $92 \%$ \\
\hline \multirow{3}{*}{9} & \multirow{3}{*}{ Annonaceae } & Annona muricata & Sirsak & Garoso Jawa & $85 \%$ \\
\hline & & Annona squamosal & Srikaya & Garoso Mbudi & $90 \%$ \\
\hline & & Muntingia calabura & Kersen & Anggo & $80 \%$ \\
\hline 10 & Muntingiaceae & Schleichera oleosa & Kesambi & Sambi & $91 \%$ \\
\hline 11 & Sapindaceae & Lagerstromeia speciosa & Bungur & Rondu & $66 \%$ \\
\hline 12 & Lythraceae & Tinospora crispa & Brotowali & Tamba & $76 \%$ \\
\hline 13 & Menispermaceae & Cyclea barbata Miers & Cincau Rambat & Ro'o Praja & - \\
\hline \multirow[b]{2}{*}{14} & \multirow{2}{*}{ Piperaceae } & Piper Betle L. & Sirih & Nahi & - \\
\hline & & Piper retrofractum & Cabai Hutan & Sabia & $84 \%$ \\
\hline \multirow{2}{*}{15} & \multirow{2}{*}{ Phyllanthaceae } & Elephantopus scaber & Tapak Liman & Nceha & $57 \%$ \\
\hline & & Sauropus androgynous & Katuk & Kambesi & $80 \%$ \\
\hline \multirow{3}{*}{16} & \multirow{3}{*}{ Asteraceae } & Chromolaena odorata & Kirinyuh & Golka & $91 \%$ \\
\hline & & $\begin{array}{l}\text { Crassocephalum } \\
\text { crepidioides }\end{array}$ & Sintrong & Kajabu & - \\
\hline & & Ageratum conyzoides & Bandotan & Pawu Keta & - \\
\hline \multirow{4}{*}{17} & & Euphorbia thymifolia & Patikan Cina & Kana’a Keta & $77 \%$ \\
\hline & & Euphorbia hirta & Patikan Kebo & Kana'a & $83 \%$ \\
\hline & Euphorbiaceae & Aleurites moluccana & Kemiri & Kaleli & - \\
\hline & & Jatropha curcas & Jarak Pagar & Tatanga & $91 \%$ \\
\hline 18 & Cucurbitaceae & Momordica charantia & Pare & Paria & - \\
\hline 19 & Anacardiaceae & Anacardium occidentale & Jambu Mede & Jambu Sampodo & - \\
\hline 20 & Rhamnaceae & Ziziphus mauritiana & Bidara/Widara & Rangga & - \\
\hline 21 & Crassulaceae & Kalanchoe pinnata & Cocor Bebek & - & - \\
\hline 22 & Amaranthaceae & Amaranthus spinosus & Bayam Duri & Kajara Sarui & - \\
\hline 23 & Moringaceae & Moringa oleifera & Kelor & Ro'o Parongge & - \\
\hline & & Curcuma domestica & Kunyit & Huni & $91 \%$ \\
\hline 24 & Zingiberaceae & Zingiber zerumbet & Lempuyang Gajah & Ntonu & $52 \%$ \\
\hline 25 & Mackinlayaceae & Centella asiatica & Pegagan & - & - \\
\hline 26 & Lamiaceae & Ocimum sp. & Kemangi Hutan & Pataha & - \\
\hline 27 & Arecaceae & Areca catechu & Pinang & U’a & $91 \%$ \\
\hline 28 & Protulacaceae & Portulaca sp. & Krokot & Soka & $88 \%$ \\
\hline
\end{tabular}






Gambar 2.Jumlah tumbuhan obat yang digunakan berdasarkan Famili


Gambar 3. Persentase tingkat pengetahuan masyarakat terhadap Tumbuhan

Koleksi Fabaceae sebagian besar berkhasiat sebagai tumbuhan berkhasiat obat. Bagian yang dimanfaatkan sebagai obat antara lain daun, bunga, kulit akar, dan kulit batang. Jenis-jenis Fabaceae tersebut mengandung berbagai zat metabolit yang mengandung khasiat sebagai obat demam, batuk, TBC, obat cacing, obat sakit perut, obat kulit, pegalpegal, salep mata, obat kuat. Senyawa yang dihasilkan dari tumbuhan dapat berpotensi sebagai antimikroba/bakterisida/ bakteriostatik (senyawa alkaloid, glikosida, minyak atsiri dan organik); antidiabetik (flavonoid, antosianin, sulfur organik, alkaloid, dan IAA); antitumor (alkaloid, terpen, flavonoid, liginan); dan antifertilitas (gosipiol dan diosgenin) [14]. Senyawa yang terdapat pada suku polong-polongan antara lain flavonoid, protein, stilbenoid, xanthones, triterpenes, saponin, diterpene, balsam, dan fitoalexin. Asam organik (termasuk asam malonic, asam tartaric, asam chelidonic), protein, asam galacturonic. Senyawa actogenis (polyketida) pada genus Cassia spp., dan senyawa anthraquinone pada genus Senna spp. [15]. 
Potensi lain suku polong-polongan adalah sebagai penghasil tanin. Tanin merupakan substansi penting yang terdapat di dalam tumbuhan sebagai zat penyamak kulit. Penyamakan kulit dengan bahan penyamak nabati di industri penyamakan kulit pada umumnya menggunakan bahan penyamak atau tanin dalam bentuk ekstrak padat atau larutan pekat [15]. Potensi lain polong-polongan adalah sebagai sumber pangan, pewarna alami, makanan ternak, dan bahan kerajinan.

Famili Asteraceae merupakan anggota famili terbesar kedua dalam sistem kingdom plantae. Famili Asteraceae juga mendominasi vegetasi tumbuhan di bumi dengan jumlah anggota yaitu lebih dari 24.000 - 30.000 spesies dan $1600-1700$ genera yang tersebar hampir di seluruh dunia serta mendiami kawasan hampir di semua lingkungan [16]. Beberapa jenis tanaman famili Asteraceae dapat dimanfaatkan sebagai obat tradisional, hal ini disebabkan karena famili Asteraceae memiliki komponen senyawa bioaktif, seperti seskuiterpen, lakton, triterpen pentasiklik, alkohol, alkaloid, tanin, polifenol, saponin, dan sterol yang dapat digunakan untuk bahan [17].

Gambar 3 menunjukkan bahwa rata-rata tingkat pengetahuan masyarakat terhadap masingmasing spesies tumbuhan yaitu sebesar $81 \%$. Persentase tingkat pengetahuan masyarakat yang terendah yaitu pada spesies tumbuhan Lempuyang gajah (Zingiber zerumbet) yaitu sebesar $52 \%$. Sedangkan persentase tingkat pengetahuan masyarakat yang tertinggi yaitu pada tumbuhan Jambu batu (Psidium guajava) yaitu sebesar $92 \%$.

Potensi Jambu batu (Psidium guajava)di Indonesia dijadikan obat alternative terhadap berbagai penyakit sangat besar. Air rebusan daun jambu batu telah digunakan sebagai terapi anti diare di berbagai sistem obat-obatan tradisional di negaranegara tropis. Menurut [11], melalui penelitiannya telah membuktikan bahwa ekstrak daun jambu batu dalam etanol dengan kosentrasi $20 \%$ dapat menghambat pertumbuhan bakteri penyebab diare yaitu Staphylococcus aureus dan Escherichia coli. Menurut [18] buah, daun, dan kulit batang pohon jambu batumengandung tanin. Daun jambu batu juga mengandung zat lain kecuali tan, seperti minyak atsiri, asam ursolat, asam psidiolat, asam kratogolat, asam oleanolat, asam guajaverin dan vitamin.

Salah satu tumbuhan yang dapat dimanfaatkan sebagai insektisida alami adalah tumbuhan lempuyang. Lempuyang (Zingiber zerumbet) sudah banyak diproduksi menjadi obat sintetik maupun jamu dan dan dapat pula dimanfaatkan untuk pengendalian rayap yang memiliki komponen aktif seperti flavonoid, alkaloid, terpenoid, kumarin, sterol, dan glikosida [18]. Senyawa yang aktif sebagai insektisida adalah dari golongan flavonoid dan terpenoid. Lempuyang gajah (Zingiber zerumbet) kurang diketahui oleh masyarakat Bima karena kurangnya informasi tentang manfaat dari tumbuhan tersebut [16].

\section{KESIMPULAN}

Berdasarkan hasil wawancara dan analisis yang dilakukan terhadap 30 responden yaitu :

a. Diperoleh sebanyak 10 responden yang memiliki tingkat pengetahuan lebih dari $90 \%, 14$ responden yang memiliki tingkat pengetahuan antara $70 \%-90 \%$, serta 4 responden yang memiliki tingkat pengetahuan kurang dari $70 \%$. Kondisi ini menunjukkan bahwa tingkat pengetahuan masyarakat tentang tumbuhan obat adalah sangat tinggi. Masyarakat ini merupakan warisan turun-termurun yang mereka dapat dari orang tua mereka pada zaman dulu.

b. Hasil wawancara dan identifikasi tumbuhan, terdapat 45 spesies tumbuhan dari 27 Famili yang digunakan masyarakat di Sekitar Taman Wisata Alam Madapangga untuk bahan pengobatan berbagai penyakit. Rata-rata tingkat pengetahuan masyarakat terhadap masing-masing spesies tumbuhan yaitu sebesar $81 \%$. Persentase tingkat pengetahuan masyarakat yang terendah yaitu pada spesies tumbuhan Lempuyang gajah (Zingiber zerumbet) yaitu sebesar $52 \%$. Sedangkan persentase tingkat pengetahuan masyarakat yang tertinggi yaitu pada tumbuhan Jambu batu (Psidium guajava) yaitu sebesar $92 \%$ dan $91 \%$ yaitu tumbuhan Bidara Laut (Strychnos lucida), Asam (Tamarindus indica), Kesambi (Schleichera oleosa), Kirinyuh (Chromolaena odorata), Jarak pagar (Jatropha curcas), Kunyit (Curcuma domestica) dan Pinang (Areca cathecu).

Perlu adanya penelitian lanjutan untuk menganalisis manfaat dan cara meramu dari persentasi tertinggi tumbuhan yang diketahui oleh masyarakat dan yang sering dipergunakan sebagai bahan obat.

\section{DAFTAR PUSTAKA}

[1] Rahayu, M., Sunarti, S., Sulistiarini, D., \& Prawiroatmodjo, S. (2006). Pemanfaatan tumbuhan obat secara tradisional oleh masyarakat lokal di Pulau Wawonii, Sulawesi Tenggara. Biodiversitas, 7(3), 245-250.

[2] Sudirga, S. K. (2012). Pemanfaatan Tumbuhan sebagai Obat Tradisional di Desa Trunyan Kecamatan Kintamani Kabupaten Bangli. Bumi Lestari, 4(2).

[3] Abdiyani, S. (2008). Keanekaragaman jenis tumbuhan bawah berkhasiat obat di dataran tinggi Dieng. Jurnal Penelitian Hutan dan Konservasi Alam, 5(1), 79-92.

[4] Takoy, D. M., Linda, R., \& Lovadi, I. (2013). Tumbuhan berkhasiat obat suku dayak seberuang di kawasan hutan Desa Ensabang Kecamatan Sepauk Kabupaten Sintang. Protobiont, 2(3). 
[5] Amzu, E., Sofyan, K., Prasetyo, L. B., \& Kartodihardjo, H. (2011). Sikap Masyarakat dan Konservasi: Suatu Analisis Kedawung (Parkia timoriana (DC) Merr.) sebagai Stimulus Tumbuhan Obat bagi Masyarakat, Kasus di Taman Nasional Meru Betiri. Media Konservasi, 12(1).

[6] Galingging, R. Y. (2007). Potensi plasma nutfah tanaman obat sebagai sumber biofarmaka di Kalimantan Tengah. Jurnal Pengkajian dan Pengembangan Teknologi Pertanian, 10(1), 76-83.

[7] Mismawati, A., Srisuwannaket, C., Mingvanish, W., Kuspradini, H., Kusumua, I. W., \& Niamnot, N. (2015). Phytochemical Screening and Bioactivity of Angiopteris evecta Leaves From East Kalimantan. In Pure Applied Chemistry International Conference(PACCON) (pp. 151-154).

[8] Nugroho, A. W. (2017). Konservasi Keanekaragaman Hayati Melalui Tanaman Obat Dalam Hutan Di Indonesia Dengan Teknologi Farmasi: Potensi Dan Tantangan. Jurnal Sains dan Kesehatan, 1(7), 377-383.

[9] Denny, D., \& Kalima, T. (2018). Keanekaragaman Tumbuhan Obat pada Hutan Rawa Gambut Punggualas, Taman Nasional Sebangau, Kalimantan Tengah. Buletin Plasma Nutfah, 22(2), 137148.

[10] Anwar, Y. A. S. (2013). Prospek Enzim Tanase Dalam Pengembangan Industri Di Indonesia. Jurnal Pijar Mipa, 8(1).

[11] Metananda, A.A,. 2012.Etnobotani Pangan dan Obat Masyarakat Sekitar Taman Nasional Gunung (Studi Kasus Pada Suku Sasak di Desa Jeruk Manis, Kecamatan Sikur, Kabupaten Lombok Timur, Nusa Tenggara Barat).Skripsi,Jurusan Konservasi Sumberdaya, Fakultas Kehutanan, Institut Pertanian Bogor.

[12] Syukur, R., Alam, G., Mufidah, A. R., \& Tayeb, R. (2011). Aktivitas Antiradikal
Bebas Beberapa Ekstrak Tanaman Familia Fabaceae. JST. Kesehatan, 1(1), 1411-1674.

[13] Ilhadi, I. (2016). Pengobatan Tradisional Di Nagari Toboh Ketek, Kecamatan Enam Lingkung, Kabupaten Padang Pariaman Studi Kasus: Ayam Sebagai Media Mengidentifikasi Penyakit (Doctoral dissertation, Universitas Andalas).

[14] Solikin. 2009. Potensi jenis-jenis herba liar di Kebun Raya Purwodadi sebagai obat.Proceeding Basic Science National Seminar Malang. 8, 47 -52.

[15] Danarto, S.A,. 2008. Keragaman Dan Potensi Koleksi Polong-Polongan (Fabaceae) di Kebun Raya Purwodadi.UPT - Balai Konservasi Tumbuhan Kebun Raya Purwodadi - LIPI.

[16] Simanjuntak, A.H,. 2017.Potensi Famili Asteraceae Sebagai Obat Tradisional Di Masyarakat Etnis Simalungun Kabupaten Simalungun Provinsi Sumatera Utara. Jurnal Biolink. 4, 12.

[17] Wegiera, M., Smolarz, H. D., Jedruch, M., Korczak, M., \& Koproń, K. (2012). Cytotoxic effect of some medicinal plants from Asteraceae family on J-45.01 leukemic cell line--pilot study. Acta poloniae pharmaceutica, 69(2), 263-268.

[18] Tafsir, A., \& Wardenaar, E. Uji Aktivitas Anti Rayap Ekstrak Rimpang Lempuyang Gajah (Zingiber Zerumbet Smith) terhadap Rayap Tanah (Coptotermes Curvignathus Holmgren). Jurnal Hutan Lestari, 3(2). [10] Hariana, A.H,. 2007. Tumbuhan Obat dan Khasiatnya. Penebar Swadaya, Jakarta.

[19] Viera. 2001. Microbicidal Effect of Medicinal Plant Extract (Psidium guajava L. and Carica papaya L.) upon Bacteria Isolated from Fish Musele and Known to induce Diarrhe in Children. Revista do Instituto de Medicina Tropical de Sao Paulo. Vol. 43 (3), pp. 145-148.

[20] Riduwan. 2012. Dasar-Dasar Statistika. Alfabeta, Bandung. 